\title{
ДЕЯКІ АСПЕКТИ ПЕРВИННОЇ ЕКСПЕРТИЗИ НАУКОВИХ ПРАЦЬ НА НАЯВНІСТЬ АКАДЕМІЧНОГО ПЛАГІАТУ
}

\author{
М. К. Хобзей, А. Р. Вергун \\ Львівський національний медичний університет імені Данила Галицького
}

\section{SOME ASPECTS OF PRIMARY EXAMINATION OF SCIENTIFIC WORKS IN THE PRESENCE OF ACADEMIC PLAGIARISM}

\author{
M. K. Khobzey, A. R. Verhun \\ Danylo Halytskyi Lviv National Medical University
}

\begin{abstract}
За 2015-2016 рр. у Львівському національному медичному університеті імені Данила Галицького впроваджено ряд заходів з протидії академічному плагіату. На факультетах, теоретичних та клінічних кафедрах затверджуються (з числа працівників університету: штатних викладачів, доцентів, професорів) особи, відповідальні за перевірку наукових робіт з застосуванням електронних систем програмного забезпечення антиплагіатної експертизи; не можуть призначатися викладачі-сумісники, аспіранти, здобувачі. Рекомендоване програмне забезпечення визначається та обновлюється науковим відділом. Запроваджено повноцінну поточну перевірку працівниками наукового відділу публікацій та дисертаційних робіт на предмет виявлення академічного плагіату програмами “Etxt Антиплагиат”, “AntiPlagiarism.NET” та “AdvegoPlagiatus 1.3.1.7”. За період з 01.09.2015 до 01.09.2016 р. проведено перевірку 429 наукових праць: 208 статей у фахові наукові журнали; 99 тез доповідей; 66 дисертаційних робіт та авторефератів; 14 наукових звітів; 22 методичних рекомендацій та методичних вказівок; 11 підручників та навчальних посібників, 9 монографій. Система запобігання та виявлення академічного плагіату розповсюджується на наукові та навчальні праці науково-педагогічних, наукових та інших працівників університету, докторантів, аспірантів; осіб, прикріплених до університету з метою здобуття наукового ступеня доктора філософії (кандидата наук) поза аспірантурою, та студентів. Виявлення в поданій до захисту дисертації (науковій доповіді) академічного плагіату є підставою для відмови у присудженні відповідного наукового ступеня.
\end{abstract}

During 2015-2016 in Danylo Halytskyi Lviv National Medical University there was implemented a number of measures against academic plagiarism. At the faculties, theoretical and clinical departments persons accountable for verification of the advanced studies with the use of the electronical academic plagiarism examination and detection software systems become (from a number the workers of university: regular teachers, associate professors, professors) firmly were established. Teachers, postgraduate students, aspirants can not be appointed such persons. The recommended software is securing-defined, determined, renovates and updated a research scientific department. Valuable current verification is entered by the workers of scientific department of publications and dissertation works for the purpose the exposure of academic plagiarism by the programs «Etxt Antiplagiat», "AntiPlagiarism.NET», «AdvegoPlagiatus 1.3.1.7». 429 scientific works for period from 01.09.2015 - 01.09.2016: 208 articles in professional scientific publications were examined; 99 theses of lectures; 66 dissertation works and abstracts of thesis; 14 scientific reports; 22 methodical recommendations and methodical pointing; 11 textbooks and train aid, 9 monographs. The system of prevention and exposure of academic plagiarism spreads to scientific and educational works of scientificallypedagogical, scientific and other workers of university, graduate students and postgraduate students; persons fastened on an university with the aim of receipt of scientific degree of Ph.D. (candidate of sciences) and postgraduate students. An exposure in the dissertation (to the scientific lecture) of academic plagiarism given to defence is founding for a refuse in awarding of corresponding scientific degree.

Вступ. Відповідно до ст. 32 Закону України “Про вищу освіту” вищі навчальні заклади зобов’язані вживати заходів, включаючи запровадження відповідних новітніх технологій, для запобігання та виявлення академічного плагіату в наукових роботах наукових, науково-педагогічних, педагогічних, iнших працівників і здобувачів вищої освіти $[1,4]$. Тому, відповідно до положень Цивільного кодексу
України, Закону України “Про вищу освіту”, Закону України “Про авторське право і суміжні права” [2] та Статуту університету, з метою запобігання поширенню плагіату в наукових роботах викладацького складу, докторантів, аспірантів, здобувачів наукового ступеня та студентів (зокрема кваліфікаційних робіт магістрів) усіх форм навчання [5]; розвитку навичок коректної роботи із джерелами

(c) М. К. Хобзей, А. Р. Вергун 
інформації [3]; дотримання вимог наукової етики та поваги до інтелектуальних надбань; активізації самостійності й індивідуальності при створенні авторського твору і відповідальності за порушення загальноприйнятих правил цитування розроблено Положення про протидію плагіату в університеті. Право на використання твору та дозвіл або заборону використання твору іншими особами $є$ виключними майновими правами автора твору [4], і відчуження цих прав здійснюється лише за домовленістю сторін на підставі авторського договору (ст. 15, ст. 31 Закону України [2] “Про авторське право і суміжні права”). Право авторства належить до особистих немайнових прав автора, яке не підлягає відчуженню [3, 4] і передбачає визнання іншими особами вказаного права за автором шляхом зазначення належним чином імені автора на творі та його примірниках і за будь-якого публічного використання твору (ч. 1 п. 1 ст. 14 Закону), включаючи його частини [1].

Основна частина. Мета роботи - оптимізувати автоматизовану антиплагіатну експертизу наукових праць у Львівському національному медичному університеті імені Данила Галицького відповідно до сучасних вимог та програмного забезпечення.

За 2015-2016 рр. нами впроваджено ряд заходів з протидії академічному плагіату. Підготовлено положення: "Протидія плагіату в Львівському національному медичному університеті імені Данила Галицького”. Підготовлено, затверджено на методкомі Львівського національного медичного університету імені Данила Галицького та опубліковано методичні вказівки: “Технічна експертиза наукових праць на наявність академічного плагіату”. Підготовлено до затвердження МОЗ України методичні вказівки з питань протидії плагіату в наукових роботах. Створено алгоритми технічної експертизи та виявлення академічного плагіату шляхом застосування вільно доступного програмного забезпечення. Запроваджено повноцінну поточну перевірку працівниками наукового відділу публікацій та дисертаційних робіт на предмет виявлення академічного плагіату програмами “Etxt Антиплагиат”, “AntiPlagiarism. NET” та “AdvegoPlagiatus 1.3.1.7”. Підготовлено лекцію з питань академічної доброчесності для магістрантів, аспірантів та здобувачів Львівського національного медичного університету імені Данила Галицького. Підготовлено та представлено на 4-й Міжнародній науково-практичній конференції “Наукова комунікація в цифрову епоху” в Національному університеті “Києво-Могилянська академія” наукову доповідь “Технічна експертиза наукових праць на наявність академічного плагіату: аналіз піврічного досвіду".

На факультетах, теоретичних та клінічних кафедрах затверджуються (з числа працівників університету: штатних викладачів, доцентів, професорів) особи, відповідальні за перевірку наукових робіт із застосуванням електронних систем програмного забезпечення антиплагіатної експертизи, проте не можуть призначатися викладачі-сумісники, аспіранти, здобувачі. Рекомендоване програмне забезпечення визначається та обновлюється науковим відділом. Керівники структурних підрозділів інформують працівників з вимогами щодо передачі наукових робіт для автоматизованої перевірки на плагіат [7]. Деканати факультетів, як структурних підрозділів, що здійснюють адміністративний супровід дипломних (фармацевтичний факультет) i магістерських робіт, визначають осіб із числа науково-педагогічних працівників, відповідальних за прийом, зберігання, систематизацію електронних версій та їх перевірку на плагіат.

Відповідальний за автоматичну перевірку наукових текстів та дисертаційних матеріалів вводить текст роботи в електронну систему програмного забезпечення антиплагіатної експертизи та перевіряє її на наявність плагіату [7]. Після перевірки на плагіат наукової роботи відповідальний за автоматичну перевірку наукових текстів та дисертаційних матеріалів надає висновок у роздрукованому вигляді у вигляді довідки про проведення первинної експертизи на наявність плагіату з указанням відсотка унікальності (оригінальності) текстових даних у представленій роботі особисто автору або через електронну пошту, через 2-7 днів після подання роботи; висновок додається до наукової роботи при іï̈ остаточному поданні до публікації чи захисту.

Перевірка документів на наявність плагіату проводилася для вільнодоступних аналізу (незахищених паролем) електронних варіантів, представлених у форматах: *.txt, *.rtf (Rich Text Format), *.doc (Word 97 - Word 2003), *.docx, *.docm (Word 2007-2010), *.pdf (Portable Document Format), *.odf, *.odt (Open Text Document) [5, 6, 8, 9]. За період 3 01.09.2015 до 01.09.2016 р. проведено перевірку 429 наукових праць: 208 статей у фахові наукові журнали; 99 тез доповідей; 66 дисертаційних робіт та авторефератів; 14 наукових звітів; 22 методичних рекомендацій та методичних вказівок; 11 підручників та навчальних посібників, 9 монографій. Наукова робота вводилася в електронну систему 
програмного забезпечення антиплагіатної експертизи повністю для визначення загального відсотка унікальності (оригінальності) текстових даних у представленій роботі [4, 5, 9]. Максимальний збіг текстових даних не перевищував межу 30 \% [6-9]. Відсоток унікальності (оригінальності) текстових даних для публікацій, звітів з наукової роботи, підручників, навчальних посібників та методичних матеріалів, типових дипломних (кваліфікаційних робіт) спеціалістів (фармацевтичний факультет) та магістрів не був меншим 70 \% [3, 4, 6, 10], кандидатських та докторських дисертаційних робіт - не меншим $80 \%$.

Статті у спеціалізовані журнали, наукові роботи (включаючи дисертаційні) та наукові звіти кафедр рецензувалися відповідальним за технічну експертизу наукових робіт старшим інспектором наукового відділу за скеруванням структурного підрозділу університету [5]. Довідка про автоматизований аналіз роботи на плагіат підшивалася до скерування та (або) відгуку установи; зберігається і є обов’ язковою для допуску наукової роботи до публікації чи до захисту [3, 4, 9, 10]. Виявлення фактів плагіату (компіляцій) у роботах осіб викладацького складу програмним забезпеченням (ПЗ) “Advego Plagiatus 1.3.1.7” або “AntiPlagiarismNET” (“Etxt Антиплагиат”) може бути враховано при продовженні дії контракту. Встановлення фактів плагіату (компіляцій) в уже опублікованих наукових роботах докторантів, аспірантів, здобувачів наукового ступеня $є$ підставою для заборони автору включати такі твори у перелік своїх науково-методичних публікацій [5].

Нами розроблена логічна проста функціональна послідовність антиплагітної експертизи дисертаційних робіт та авторефератів, створена за допомогою сучасного офісного україномовного ПЗ різних розробників з проведенням аналізу відсотка унікальності тексту методом шингла ПЗ “Advego Plagiatus 1.3.1.7” та “AntiPlagiarismNET” (“Etxt Антиплагиат”) з оптимізованими налаштуваннями параметрів глибокого пошуку [4, 7-10] та глибокою перевіркою по 5-7 пошукових системах [5, 7, 8]. Перевірка автореферату П3 “Advego Plagiatus 1.3.1.7”, шингл 4, пошукова фраза 5 слів, глибока перевірка проводиться по 5 пошукових системах з виведенням відсотка унікальності тексту та трансляцією звіту (виконанням розширеної “розверстки” звіту - перевіреного тексту та результатів перевірки). Аналіз першого розділу дисертацій (огляду літератури) здійснюється ПЗ “Advego Plagiatus 1.3.1.7”, шингл 4, пошукова фраза 5 слів, виконується глибока перевірка з виведенням відсотка унікальності тексту й формуванням звіту. Також здійснюється перевірка тексту розділів власних досліджень дисертаційної роботи ПЗ “Advego Plagiatus 1.3.1.7”, шингл 4, пошукова фраза 5 слів, глибока перевірка по 5 пошукових системах з виведенням відсотка унікальності тексту. Повна (тотальна) експертиза тексту дисертаційної роботи П3 “AntiPlagiarismNET” (“Etxt Антиплагиат”) виконується 3 застосуванням таких налаштувань: шингл 5, глибока перевірка з виведенням відсотка унікальності тексту та трансляцією звіту (виконанням розширеної “розверстки” звіту - перевіреного тексту дисертаційної роботи та результатів перевірки). Формування деталізованого звіту здійснюється щодо перевірених документів та 4-х фрагментів; загальний відсоток унікальності тексту автореферату формується ПЗ “Advego Plagiatus 1.3.1.7”, шингл 4, пошукова фраза 5 слів, глибока перевірка по 5 пошукових системах; загальний відсоток унікальності тексту дисертацій формується “AntiPlagiarismNET” (“Etxt Антиплагиат”), шингл 5, глибока перевірка по 7 пошукових системах; інші дані мають додаткове значення для експерта, щодо визначення явного плагіату у рецензованому матеріалі при виникненні необхідності подальшого дослідження збігів [5, 7, 8].

Виявлення факту академічного плагіату у наукових роботах можливе на етапі представлення вченому секретареві, в редакцію або для розгляду на Вченій раді з метою рекомендації до друку - для наукових робіт (монографія, підручник, навчальний посібник, стаття, тези тощо); на етапі розгляду на засіданні кафедри наукових чи навчальних матеріалів, що вимагають ухвалення кафедри; на етапі подання на перевірку викладачеві студентських (кваліфікаційних) робіт [5-7, 10]. Відповідно до правил, встановлених ч. 6 ст. 6 Закону України “Про вищу освіту”, до захисту допускаються дисертації (наукові доповіді), самостійно виконані здобувачем наукового ступеня. Виявлення в поданій до захисту дисертації (науковій доповіді) академічного плагіату є підставою для відмови у присудженні відповідного наукового ступеня.

Враховуючи наявність обмежень у П3 “Advego Plagiatus 1.3.1.7” щодо обсягу тексту до 200000 символів при відсутності такого обмеження у ПЗ “AntiPlagiarismNET” (“Etxt Антиплагиат”), загальну перевірку тексту дисертаційної роботи та інших текстів великого обсягу рекомендуємо проводити “AntiPlagiarismNET” (“Etxt Антиплагиат”) з одно- 
моментною послідовною перевіркою автореферату, першого розділу дисертації, сумарного тексту розділів власних досліджень П3 “Advego Plagiatus 1.3.1.7”, шингл 4, глибока перевірка по 5 пошукових системах зі створенням окремих файлів розверстки для подальшого порівняння та аналізу. Нами стверджено, що одночасна перевірка автореферату та тексту дисертаційної роботи з застосуванням різного ПЗ є цілком можливою (одномоментне застосування ПЗ “Advego Plagiatus 1.3.1.7” та ПЗ “AntiPlagiarismNET” (“Etxt Антиплагиат”) добре реалізується) при достатньо потужному апаратному забезпеченні $[5,7]$. Такий підхід також сприяє значно більшій об'єктивності отриманих відсотків унікальності при виникненні нестандартних ситуацій, спричинених недосконалістю ПЗ та при тимчасовому відключенні чи блокуванні доступу до окремих пошукових систем та серверів. Перевірка тез доповідей та статей у фахові журнали здійснюється за допомогою програмного ПЗ “Advego Plagiatus 1.3.1.7”, “AntiPlagiarismNET” (“Еtxt Антиплагиат”). Система запобігання та виявлення академічного плагіату розповсюджується на наукові та навчальні праці науково-педагогічних, наукових та інших

\section{Список літератури}

1. Артамонов Є. Б. Аналіз методів протидії автоматичним системам визначення плагіату в електронних документах / Є. Б. Артамонов // Проблеми інформатизації та управління. - 2012. - № 4 (40). - С. 12-18.

2. Закон України “Про авторське право і суміжні права” // Законодавство України про охорону інтелектуальної власності. За станом на 25 червня 2007 р. / Верховна Рада України. - Офіц. вид. - К. : Парлам. вид-во, 2007.

3. Капіца Ю. Спеціальні механізми захисту авторського права і суміжних прав в Інтернеті / Ю. Капіца, О. Рассомахіна, К. Шахбазян // Інтелектуальна власність. - 2012. -№ 4. - С. 13-24.

4. Ковальова А. Проблеми академічного плагіату та авторського права / А. Ковальова // Спеціальні історичні дисципліни. - 2014. - № 21. - С. 61-71.

5. Чоп’як В. В. Технічна експертиза наукових праць на наявність академічного плагіату: аналіз піврічного працівників університету, докторантів, аспірантів; осіб, прикріплених до університету з метою здобуття наукового ступеня доктора філософії (кандидата наук) поза аспірантурою, та студентів.

Висновки: 1. Одним із сучасних напрямків боротьби з академічним плагіатом $€$ його виявлення i констатація за допомогою комп'ютерних ресурсів, існує ефективне програмне забезпечення, яке допомагає встановити відсоток унікальності тексту.

2. Технічна антиплагіатна експертиза наукових праць, дисертаційних робіт та авторефератів на наявність плагіату проводиться програмним забезпеченням “Advego Plagiatus 1.3.1.7” та “AntiPlagiarismNET” (“Etxt Антиплагиат”) для встановлення відсотків унікальності тексту у відповідності 3 даними інтернет-ресурсів щодо безкоштовного програмного повнофункціонального забезпечення для застосування в різних операційних системах.

3. Викладачі, докторанти, аспіранти, здобувачі наукового ступеня та студенти усіх форм навчання несуть відповідальність за подання своєї науково-дослідницької роботи згідно з результатами антиплагіатної експертизи.

досвіду / В. В. Чоп’як, О. Б. Надрага, А. Р. Вергун // Медична освіта. - 2016. - № 1 (69). - С. 50-53.

6. Prevalence of Plagiarism Medical Students / L. BiliaeZulle, V. Frkoviae, T. Turk [et al.] // Croat. Med. J. - 2005. № 46 (1). - P. 126-131.

7. Cognitive Technologies представляє Систему автоматичного аналізу та порівняння текстів [Електронний ресурс]. - Режим доступу : http://iukraine.runwww.iukraine. ru/2011/12/19/cognitive_technologies_predstavlya_ sistemu_avtomatichnogo_analzu_ta_porvnyannya_tekstv. html. /- Назва з екрана.

8. http://studway.com.ua/akademichniy-plagiat/- Назва 3 екрана.

9. http://tdo.at.ua/publ/distance_education/plagiat/1-1-0-45/Назва $з$ екрана.

10. http://vkurse.ua/ua/technology/obnaruzheniyaplagiatav-tekstakh.html/- Назва з екрана. 